\title{
Evolution of cranioplasty techniques in neurosurgery: historical review, pediatric considerations, and current trends
}

\author{
${ }^{*}$ Abdullah H. Feroze, BS, ${ }^{1}$ Graham G. Walmsley, BA, ${ }^{1}$ Omar Choudhri, MD, ${ }^{2}$ H. Peter Lorenz, MD, ${ }^{3}$ \\ Gerald A. Grant, MD, ${ }^{2}$ and Michael S. B. Edwards, MD² \\ ${ }^{1}$ Institute for Stem Cell Biology and Regenerative Medicine, Stanford University School of Medicine; ${ }^{2}$ Division of Pediatric \\ Neurosurgery, Department of Neurosurgery, Lucille Packard Children's Hospital; and 'Division of Plastic and Reconstructive \\ Surgery, Department of Surgery, Lucille Packard Children's Hospital, Stanford University School of Medicine, Stanford, California

\begin{abstract}
Cranial bone repair is one of the oldest neurosurgical practices. Reconstructing the natural contours of the skull has challenged the ingenuity of surgeons from antiquity to the present day. Given the continuous improvement of neurosurgical and emergency care over the past century, more patients survive such head injuries, thus necessitating more than ever before a simple, safe, and durable means of correcting skull defects. In response, numerous techniques and materials have been devised as the art of cranioplasty has progressed. Although the goals of cranioplasty remain the same, the evolution of techniques and diversity of materials used serves as testimony to the complexity of this task. This paper highlights the evolution of these materials and techniques, with a particular focus on the implications for managing pediatric calvarial repair and emerging trends within the field.
\end{abstract}

http://thejns.org/doi/abs/10.3171/2014.11.JNS14622

KEY WORDS cranioplasty; pediatric; autograft; allograft; methylmethacrylate; hydroxyapatite; induced pluripotent stem cells; bone morphogenetic protein; neurosurgical history; surgical technique

$\mathrm{T}$ HE practice of cranial reconstruction dates at least as far back as $3000 \mathrm{BC}$, where archeological evidence suggests the repair of head trephination with the use of precious metals, shells, and gourds by the ancient Incans in what is now Peru (Fig. 1). The procedures were probably performed on living subjects rather than postmortem; cases of recovered archaeological finds have yielded crania healed tightly around foreign bodies. ${ }^{100,104}$ Similar historical evidence has been found from ancient Celtic, Persian, Turkish, and South American civilizations. ${ }^{3,32,34,97,106}$

Few subsequent advances were made in the practice of cranioplasty until Galen (130-200 AD) and Avicenna (980-1037 AD) started using moistened linen over wounds and performed regular dressing changes to promote wound granulation, a practice that was followed for centuries. ${ }^{82,104}$
In $1505 \mathrm{AD}$, the Ottoman surgeon Ibrahim bin Abdullah published the first known written case of cranioplasty in his book, Wonders of Surgeons (Alâim-i Cerrâhin), a case that was treated using goat- and canine-derived xenografts. ${ }^{1,10}$ The practice of repairing cranial lesions with metal plates was introduced soon thereafter to Europe by the writings of Fallopius and Petronius in the late 16th century, but it was not until almost a century later, in 1668, that the Dutch surgeon Job Janszoon van Meekeren reported the first successful bone graft cranioplasty. Van Meekeren, although he was not the surgeon who should have received credit, documented the use of a canine xenograft to correct the calvarial defect caused in a Russian nobleman by the blow of a sword. The nobleman, Butterlijn, was restored to full health, but the work was poorly received by Butterlijn's contemporaries. At the risk of excommunication by the

ABBREVIATIONS ASC = adipose-derived stem cell; BMP = bone morphogenetic protein; BMSC = bone marrow-derived stem cell; iPSC = induced pluripotent stem cell; $M M A=$ methyl methacrylate; $P E E K=$ polyetheretherketone

SUBMITTED March 18, 2014. ACCEPTED November 25, 2014.

INCLUDE WHEN CITING Published online February 20, 2015; DOI: 10.3171/2014.11.JNS14622.

DISCLOSURE Dr. Lorenz is a consultant for Synthes for a soft-tissue fascia reconstruction device that is unrelated to cranioplasty.

* Mr. Feroze and Mr. Walmsley contributed equally to this work. 


\section{Cranioplasty over the years}

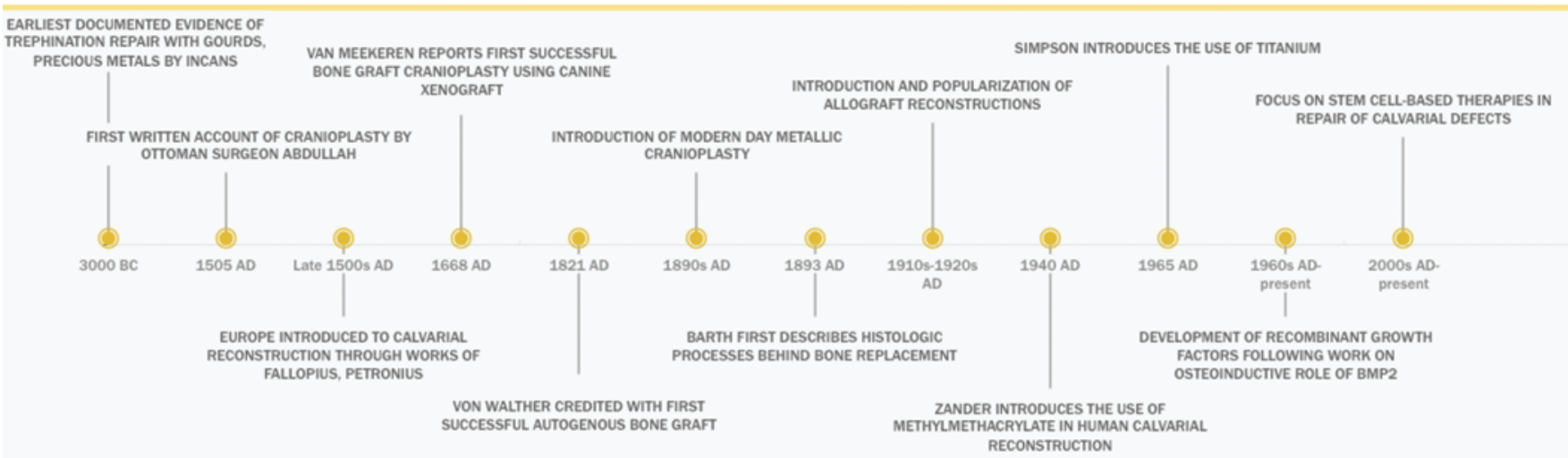

FIG. 1. Timeline of the history of cranioplasty. The names and dates provided are correct to the best of our knowledge, given the limitations of our source material. Figure is available in color online only.

Russian church for "marring God's image," he begged his surgeon to remove the implant. The surgeon was unable to remove the firmly implanted canine bone, however, and Butterlijn was forced to flee the country. ${ }^{88,104}$

Such early attempts, however rudimentary, ushered in a new age of innovation in the field, as surgeons realized the need to understand the unique properties of the cranium just as much as those of the brain itself. From the earliest use of gourds and metals until the present day, materials used for cranioplasties have been a reflection of the interplay of durability, biocompatibility, and availability. We offer a brief historical account and review of current literature on such materials.

\section{Autografts}

Given the ultimate goal of cranioplasty to reproduce the structure and function of absent calvaria to the greatest degree possible, the merits of autologous bone are obvious, including marked strength and elasticity, biocompatibility, general availability, and resistance to infection. Given the low cost of conservation, lower rates of infection compared with many other types of prostheses, and assured biocompatibility, the autologous cranial flap remains the gold standard in calvarial repair. ${ }^{4}$

In 1821, von Walther performed the first human autologous bone graft shortly following documented animal experiments by Merrem in $1810.9^{90,130}$ The importance of the periosteum in bone regeneration was established soon thereafter by the work of Ollier in $1859 .{ }^{19}$ The Scottish physician William MacEwen established himself as the founder of the modern practice of bone grafting following his work in 1878, in which he successfully reimplanted calvarial bone fragments. In 1889, Seydel transplanted a tibial autograft with periosteum intact for the successful repair of a parietal defect, which was followed by the successful transplantations of autologous calvarial bone grafts by Muller (1890), temporalis muscle and fascia by Beck (1906), whole ribs by Dobrotworski (1911), scapula by Röpke (1912), ilium by Mauclaire (1914), and split ribs by Brown (1917), $, 2,27,40,78,103,130$ The technique was further advanced by the work of Longacre and DeStefano in 1957, who pioneered the use of autologous split rib grafts to repair large cranial defects, as is practiced today ${ }^{69,70}$ Tessier subsequently ushered in the era of pediatric craniofacial reconstruction through the use of autologous techniques in $1967 .{ }^{116}$

Today, split calvarial grafts demonstrate relatively lowrisk profiles with minimal donor-site morbidity in adult and pediatric populations alike. ${ }^{31,44,58,124}$ However, this approach is of limited utility in children under the age of 4 years, given the limited calvarial thickness and availability of donor bone. Full-thickness and split rib grafts have also shown satisfactory results in children, even in the setting of large cranial defects, but the pain caused by a multilevel rib resection is considerable. $.^{60,80,91,114} \mathrm{Ad}-$ ditionally, there have been limited reported cases on the tendency of children to suffer aseptic resorption of sterilized bone flaps, which is hypothesized to be attributable to an array of possible causes, from inherent hyperactive cellular responses to the degree of calvarial thickness in this subpopulation. ${ }^{41,45,51}$

Disillusionment with autologous bone cranioplasty continues to exist given the propensity for resorption (reported rates are as high at $50 \%$ across all age groups), ${ }^{8,41,113}$ inadequate contouring, debate over optimal means of bone flap preservation, $, 50,83,95$ and potential for donor-site morbidity; these in sum continue to limit the use of this biomaterial for a broader spectrum of patients..$^{15,120}$

\section{Allografts}

Sicard, Dambrin, and Roger introduced the use of cadaveric skull in cranioplasty during the latter half of the 1910s. ${ }^{19}$ In 1915, Morestin introduced the use of cadaveric cartilage, which became the cranioplasty technique of choice during World War I, but soon thereafter the technique fell out of favor, given the lack of significant tissue calcification and strength. ${ }^{77,81}$ Additionally, the advent of cadaveric cranial grafts was initially fraught with complications secondary to infection, which limited their practicality and efficacy. ${ }^{104}$ More recent reports have suggested moderate success in the use of cadaveric bone grafts in cranioplasty, but the use of allografts in contemporary 
cranial reconstruction remains relatively rare compared with the use of autografts and synthetic materials. ${ }^{61,122}$

\section{Alloplasts}

Over the history of cranioplasty, surgeons have struggled to find the ideal alloplastic material that confers the advantages of native bone, including durability, biocompatibility, and availability, with a low risk of infection. Even today, no such material possesses all of these properties. ${ }^{28}$ Several options, including metals, acrylics, ceramics, and plastics, have been used with varying degrees of success.

\section{Metals}

Multiple metals have been the subjects of trials in the quest for the perfect medium since aluminum and gold were popularized by Booth and Gersten, respectively, in the 1890s. Over the past century, metals in which trials have been conducted for use in human subjects have included vitallium alloys by Geib (1941); tantalum by Pudenz and Odom (1942); stainless steel mesh by Boldrey (1944); stainless steel by Scott, Wycis, and Murtagh (1956); and titanium by Simpson (1965).94,118 Vitallium, an alloy of cobalt, molybdenum, and chromium, demonstrated decreased bone necrosis and metal corrosion in comparison with pure metals; however, its lack of malleability made intraoperative shaping difficult. By the late 1940s it was no longer used in the repair of cranial defects. Tantalum was used for a brief period during World War II but due to price, limited supply, and complications from high thermal conduction, its use was discontinued shortly thereafter.

Many of the aforementioned metals have fallen out of favor due to the introduction of stronger, more conformable, and osteocompatible materials. Other limitations as well, such as the potential for epileptogenesis, plate dislodgement and subsequent scalp erosion and perforation, and the creation of a potential dead space into which brain can herniate or hematoma can form, have led to diminished interest in the use of metals for cranioplasty. ${ }^{105,111}$ However, titanium has stood the test of time. From its earliest uses during World War II, the material remains a mainstay of modern cranioplasty practice, particularly given modern alloys mixed with metals such as aluminum to create increasingly affordable, bio-inert, and heat-resistant agents. ${ }^{39,108}$ Complication rates - primarily delayed infection-associated with use of the material approximate $10 \%$, with no discrepancy in reported rates across adult versus pediatric cohorts. ${ }^{11,101}$

The advent of computer-assisted design has allowed for the production of increasingly popular customized, prefabricated titanium plates for adult patients. ${ }^{35,54} \mathrm{Ad}-$ ditional advances, such as titanium mesh combined with hydroxyapatite and other alloplasts, have also allowed for substances that provide improved osteointegration with adequate aesthetic restoration of cranial contour and with minimal side effects in the treatment of larger cranial defects, even in the setting of pediatric procedures. ${ }^{11,17,29,127} \mathrm{In}$ a recent retrospective analysis by Williams et al., ${ }^{23}$ pediatric patients underwent titanium cranioplasty for a mean defect size of $41.8 \mathrm{~cm}^{2}$ (range $5.3 \mathrm{~cm}^{2}-116.5 \mathrm{~cm}^{2}$ ) with no noted complications after 1 year of follow-up. ${ }^{128}$

Radiographic attenuation caused by metallic cranioplasty can create imaging artifacts with CT scans and radiographs. The degree of radiographic attenuation is based on the atomic number of the metal used, and is therefore higher with tantalum and gold compared with titanium. ${ }^{18}$ The extent of scatter caused by metallic cranioplasty becomes an important consideration in patients who require radiation therapy following cranioplasty. The backscatter can potentially cause local overdose with skin necrosis and underdosing to deeper tissues such as tumors, resulting in inadequate treatment. However, the inhomogeneity in high energy photon dose distribution and proton beam dosimetry caused by titanium mesh $(0.4-0.6 \mathrm{~mm})$ is minimal. ${ }^{67,89}$ Superficial and deep tumors can therefore be irradiated through a $0.4-\mathrm{mm}$ titanium mesh without concerns of under- or overdose from backscatter. Similarly, titanium mesh has minimal effect $(<3 \%)$ on dosimetry during Gamma Knife radiosurgery. ${ }^{96}$

\section{Acrylics}

Initially manufactured as an industrial material in the 1930s (Plexiglas), methyl methacrylate (MMA) was repurposed for use in human calvarial repair by Zander in 1940, and was popularized by the published work of Gurdjian et al. soon thereafter. ${ }^{43,111,130}$ As an inexpensive, readily available, and biocompatible polymeric alternative to ceramics and metals, MMA also quickly gained favor as an agent for skull reconstruction given shorter operating times than traditional autograft methods, without associated postoperative pain and donor site disfigurement.

This material continues to be the most widely used choice for adult cranioplasty procedures given its intraoperative malleability and generally favorable long-term outcomes across a wide variety of indications. ${ }^{73}$ However, given its lack of osteointegration and its brittle nature despite attempts at reinforcement with metallic wire mesh and other materials, ${ }^{36,47,53,105}$ regardless of initially favorable reviews in the pediatric setting, the material is now largely only of historical interest in children. ${ }^{85,121}$ It is widely believed that acrylic cranioplasty should be avoided in children, particularly those less than 5 years of age. ${ }^{16,55}$

Overall complication rates from the use of MMA vary greatly depending on published series, ranging from $5 \%$ to $40 \%$. Infection rates of $5 \%$ to $20 \%$ are particularly elevated in the setting of frontal cranioplasty given sinus communication, risk for infection, and possible fistulization. ${ }^{2,13,26,52,73,76,93}$ Complication rates quoted within the pediatric population reach as high as $23 \%$, as reported by Blum et al. in their 15-year retrospective review of 75 patients, with those patients with large defects, involvement of the frontal sinus, and any history of prior infection at the greatest risk..$^{13}$ Other rare but notable side effects of the material include delayed-type hypersensitivity reactions, which are seen in approximately $1 \%$ of patients. ${ }^{37}$

\section{Ceramics}

Materials such as hydroxyapatite and coralline carbonated calcium phosphate cement (CCPC) have gained in- 
creasing traction as materials for calvarial reconstruction over the past few decades, given their ease of application and ability to conform to most defect shapes (Fig. 2). Initially limited by its poor tensile strength and impact resistance, more recent formulations of hydroxyapatite coupled with agents such as calcium sulfate hemihydrate (plaster of Paris) and titanium mesh have enabled the isothermic application of the material, which closely mimics the behavior of native bone, with a high degree of biocompatibility, tensile strength, and osteointegration, given its macroporosity as an organic agent. . $5,29,30,49,57,98$ Additionally, as a synthetic equivalent of the naturally occurring mineral found in bones and teeth, there is virtually no foreign body reaction noted on implantation.

Recent studies indicate that bioceramics are comparable to autologous bone flaps following decompressive craniectomies and subsequent repair, given the advent of computer-assisted design to create custom-fitted materials. Cost, however, remains a large barrier to increased utilization of such materials. , $64,84,112$ Other limitations include the increased propensity to fracture due to transfer of CSF pulsations through the dura mater, elevated complication rates in the setting of trauma, and use of hydroxyapatite in areas of potential communication with the sinuses..$^{74,109,129}$

\section{Plastics}

Celluloid was one of the first alloplasts for which trials were conducted in the late 1800s by Fränkel, but it was ultimately discarded due to biodegradative processes in tissues comprising its functionality ${ }^{40}$ However, the newer plastic polymers, including porous polyethylene and polyetheretherketone (PEEK), have proven advantageous in a number of modern settings as nondegradable and durable agents for calvarial repair. As prefabricated agents that can be used for small and large defects alike, one particular advantage of porous polyethylene is its framework that allows for theoretical bony ingrowth and vascularization, although more recent literature has called such osteoconductive properties into question. ${ }^{68,115,126}$ Alternatively, although PEEK implants lack osteoconductive properties, as an inert and easily removable material they prove useful in settings where repeated intracranial access may be necessary.

\section{Considerations in Pediatric Cranioplasty}

Pediatric cranial defects can be acquired (i.e., trauma, infection, neoplasm) or congenital (i.e., parietal foramina, cleidocranial dysplasia, cutis aplasia, craniosynostosis). While many acquired pediatric cranial deformities in very young children may close spontaneously, especially in instances in which dura and pericranium remain intact, larger defects and those secondary to congenital anomalies typically require surgical intervention (Figs. 3 and 4). The osteogenic potential of the cranium is inversely proportional to age and decreases rapidly after 1 year of age. Whereas reconstructive strategies for cranial defects in older children and adults include autologous bone grafts, bone substitutes, and synthetic materials, there are considerations in pediatric cranioplasty limiting the range of available reconstructive options. In addition, the risk for bone resorption with an autologous implant remains high in the pediatric population. Methods to decrease the rate of absorption have included the need to secure the thin flap with additional fixation as well as to augment the gaps with synthetic bone or mesh at the time of the cranioplasty. The autologous flap can often loosen over time due to the prominent brain pulsations in children, which is thought to exacerbate the resorption. ${ }^{41}$

Growth of the pediatric cranium, with accompanying bony contour changes, places limitations on useable bone substitutes. Similarly, emerging data suggest time as a predictive factor of long-term outcomes, such as for autologous cranioplasty in the setting of pediatric decompressive craniectomy. ${ }^{92}$ Commonly used bone substitutes in adult cranioplasty do not have the capacity for growth and are thus problematic for applications in pediatric cranioplasty. Many studies have therefore found that autologous skull bone grafts are superior to materials such as acrylic or metals for cranioplasty in children. ${ }^{31,80}$ Autologous bone
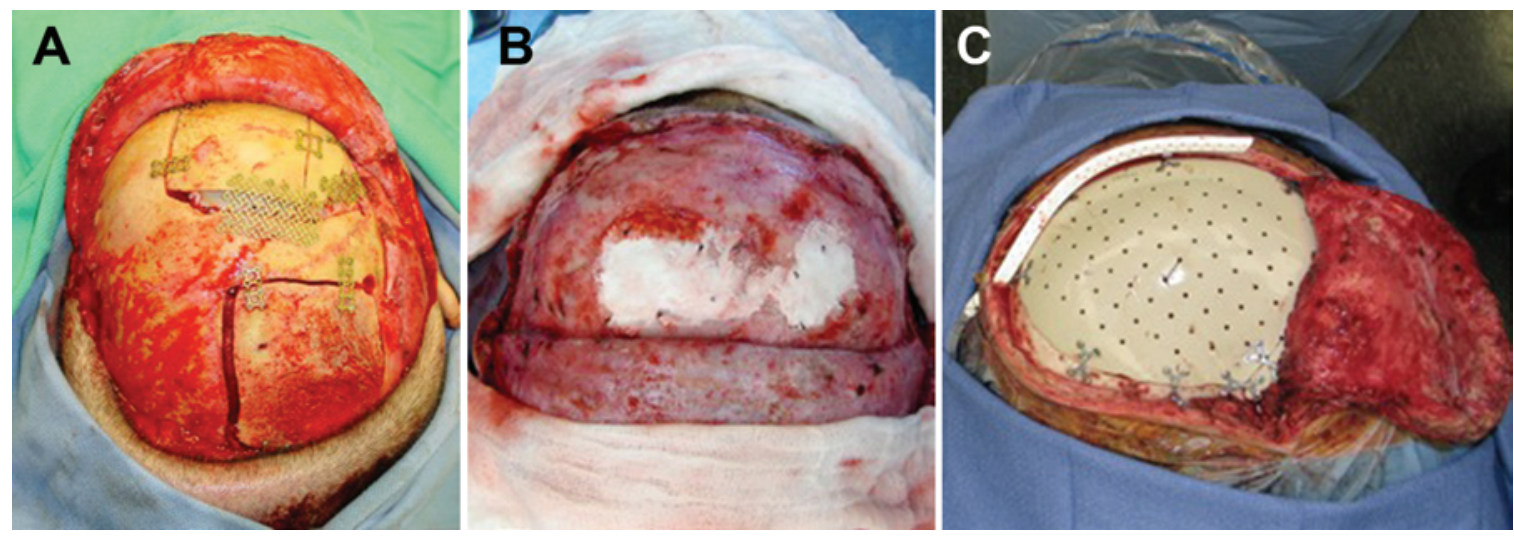

FIG. 2. Representative intraoperative images of current cranioplasty materials. A: Right parietal split calvarial bone graft with titanium plate and mesh used for the repair of a right frontal forehead defect after tumor resection, radiation, and bone flap removal in a 38-year-old patient. Dura was reconstructed with bovine pericardium. B: Hydroxyapatite cement and resorbable plate repair of 2 defects on the upper forehead in a 9-year-old child following metopic repair during the 1st year of life. C: Custom-made PEEK implant used for cranioplasty in a 30-year-old woman with a defect of right frontal and temporoparietal areas. 

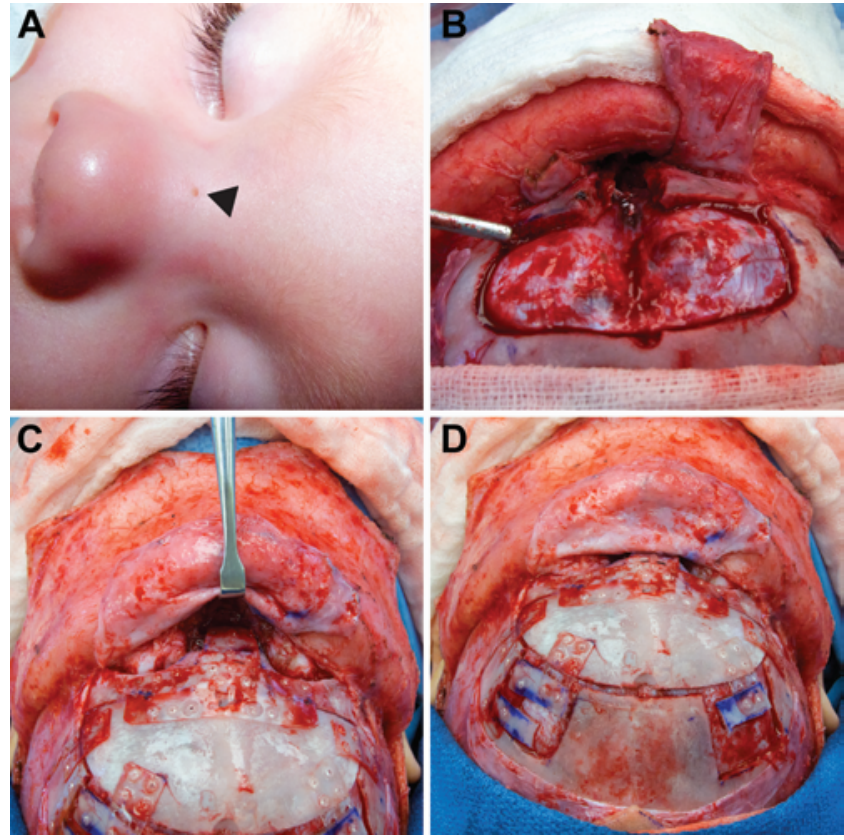

FIG. 3. Autologous pediatric cranioplasty repair of nasal dermoid by using resorbable plates in a 2-year-old boy. A: Photograph showing the site of the nasal dermal sinus tract (arrowhead). B: Bifrontal craniotomy with removal of nasal bridge. C and D: Cranioplasty construct made using resorbable plates and harvested pericranium.

flaps have also demonstrated success in pediatric cranioplasty ${ }^{131}$ A study in 2002 suggested that osteogaleal flaps are an ideal choice for reconstruction in pediatric defects due to their membranous origin, ease of harvest, reliable vascularity, and applicability to any part of the calvaria. ${ }^{86}$

Although hydroxyapatite and demineralized bone matrix have been used to reconstruct cranial defects in children, such materials are hindered by higher rates of infection (especially adjacent to the frontal sinus), questionable long-term stability, and limited potential for osteointegration in comparison with autologous bone. ${ }^{33,79}$ A study in 1998 used coralline hydroxyapatite granules mixed with Avitene and autologous blood for the reconstruction of pediatric cranial bone defects, with great success. ${ }^{22}$ Pang et al. improved the stability of hydroxyapatite by using bioresorbable perforated plates to dampen CSF pulsations. ${ }^{87}$ Other studies have used polylactic acid absorbable plates and carbonated apatite bone cement to similar effect. ${ }^{24}$ The development of such reconstructive strategies by using bone substitutes that avoid rigid fixation and promote graft transformation into viable tissue is a critical step toward improving cranioplasty outcomes in pediatric populations. Biomaterials containing osteoinductive factors such as bone morphogenetic protein (BMP) represent a promising area of research, but their use in clinical settings, particularly for pediatric cranioplastic applications, needs to be further explored.

Although autologous bone is the standard material used for cranioplasty in adults, its supply is limited in children. A recent study examining the architecture of the pediatric cranium recommended that split cranial bone grafting be performed only after 3 years of age, and in situ cranial bone grafting only after 9 years of age. ${ }^{59}$ Before 3 years of age, the diploic space is not reliably present and the skull is thin. Extracranial sources of bone such as the rib and iliac crest are limited in volume, associated with higher resorptive rates than cranial bone, ${ }^{132}$ and prone to complications including pneumothorax, chest wall deformity, reduced sensation of the lateral femoral cutaneous nerve, and gait disturbances. ${ }^{63}$ Finally, autologous cranial grafts suffer from donor-site morbidity and limited contouring plasticity. A push to use synthetic materials such as porous polyethylene and MMA due to the aforementioned concerns with autologous bone grafts has been met with limited success due to the inability of these materials to osteointegrate and their tendency to destabilize during growth.

Recently, autologous cranial particulate bone grafts mixed with autologous blood have been shown to effectively heal cranial defects in children, with minimal morbidity. ${ }^{42}$ Particulate grafts consist of small pieces of bone harvested with a low-speed bit brace and offer a means to use autologous pediatric cranial bone without the shortcomings associated with split cranial bone grafting. ${ }^{23,102}$ Advantages include increased malleability and a larger available volume of bone, in part due to additional regions of harvestable cranium (i.e., mastoid and occiput), which are not amenable to the split calvarial technique. Harvesting particulate bone is both safer and easier than a split cranial graft because a craniotomy is not required. Finally, particulate grafts can be harvested in infants before the formation of the diploic space, a major limitation of the split calvarial technique. However, due to a lack of structural integrity until healing nears completion, particulate grafts cannot be used in cranial sites without underlying bony or dural support.

Scalp reconstruction is closely tied with successful pediatric and adult cranioplasty, because significant scalp contraction can occur with bony skull defects. Primary scalp closure is only possible for small cranial defects $(3-4 \mathrm{~cm})$ after wide undermining of the subgaleal plane. ${ }^{75}$ In patients undergoing cranioplasty for large cranial defects related to tumor resection or head trauma, primary scalp closure is often not possible. Skin grafting and local rotational flaps may be used in these reconstructions. Free flaps are being increasingly used for reconstruction after large complex cranioplasties. These include latissimus dorsi myocutaneous flap, rectus abdominus flap, radial forearm flap, and omentum flap, among others. ${ }^{62,75}$ Preoperative subgaleal scalp expansion is another technique that avoids morbidity associated with free tissue transfer, and has been successfully used with large skull reconstructions. ${ }^{56}$ Choice of a scalp coverage technique is determined by the anatomy (size, depth, and axial blood supply) and physiology (radiation, infection) of the defect in addition to patient factors such as comorbidities, oncological issues, and cosmetic concerns. ${ }^{107}$

\section{Current Practice and Future Trends}

Despite the history of cranioplasty spanning thousands of years, modern cranioplasty has only been in practice since the second half of the last century. As religion, warfare, and primitive medical practices fueled innovation in 

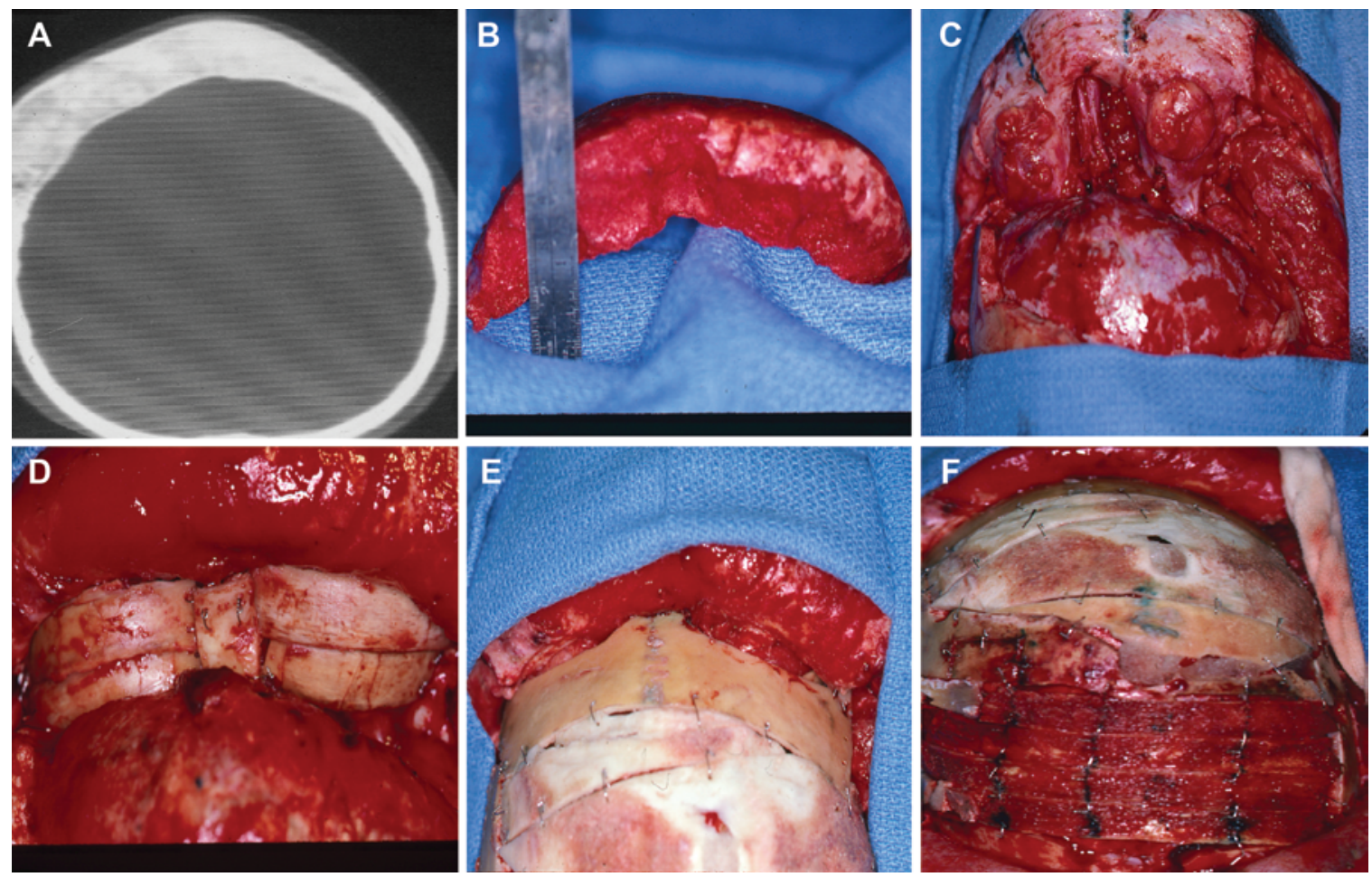

FIG. 4. Cranioplasty for craniofacial fibrous dysplasia in a 13-year-old girl. A: Head CT scan obtained without contrast showing increased calvarial thickness with sclerosis secondary to fibrous dysplasia. B: Hyperostotic orbital bar following craniectomy. C: Intraoperative view after completion of a bifrontal craniotomy and removal of orbital bar. D: Reconstruction of orbital roof with split rib grafts. E and F: Reconstruction of calvaria using split calvarial grafts and multiple split rib grafts at the site of the craniectomy defect.

the field centuries ago, many of the advances made in the modern day recapitulation of cranial structure and function can be attributed to decompressive craniectomies secondary to acute ischemic stroke and traumatic injury. As enhanced technological capabilities on the battlefield coupled with advances in the operating room have enabled more soldiers to survive traumatic brain injury secondary to blast injuries, the number of craniectomy defects has jumped exponentially over the past few decades, catalyzing the development of new cranioplasty tools and techniques within the realm of regenerative medicine.

\section{Growth Factors}

The histological premise behind bone replacement, where transplanted bone cells die but leave a scaffolding on which living bone can form, was first described by Barth (1893). ${ }^{7}$ As our understanding of the basic molecular biology and physiology of bone graft healing improves, from the importance of revascularization and osteoinduction to osteoconduction and osteogenesis, the use of novel calvarial reconstruction agents along with recombinant human bone growth factors has become increasingly prevalent. Extensive research exists on the use of recombinant factors such as transforming growth factor $\beta$, insulin-like growth factor-I, and BMP-2 in augmenting calvarial closure in animal and human models. ${ }^{12,48,71,99,123}$ In 1965, Urist first documented the osteoinductive capacity of demineralized bone matrix, and subsequent research led to the popularization of BMP-2 and related factors. ${ }^{119}$ The field of tissue engineering also bears equally great ramifications, because exogenous production of natural materials could revolutionize therapy, particularly for patients lacking adequate donor sites, those plagued with chronic osteomyelitis, and many others.

\section{Stem Cell-Based Therapies}

Despite continued advances, an optimal method for the reconstruction of large calvarial defects remains elusive. Recent advances in laboratory research have shifted the focus of cranioplasty from osteoconduction, relying on the entrance of surrounding osteoprogenitor cells to ensure successful bone grafting, to a more osteoinductive framework, whereby undifferentiated mesenchymal cells can be transformed into osteoprogenitor cells in situ. ${ }^{21,125}$ Stem cell-based therapies hold enormous promise in this regard, with studies in mouse models demonstrating successful repair of critical-sized cranial defects by using human induced pluripotent stem cells (iPSCs), bone marrowderived stem cells (BMSCs), and adipose-derived stem cells (ASCs). ${ }^{65,66,72}$ Early clinical trials have yielded similarly promising results. A recent study of 4 patients with large calvarial defects of differing origins showed that beta-tricalcium phosphate scaffolds seeded with ASCs resulted in successful outcomes with no clinically relevant postoperative complications. ${ }^{17}$

Emerging as the frontrunner for stem cell-based repair of cranial defects, ASCs possess several advantages over BMSCs, including rapid in vitro expansion, ease of har- 
vest, and higher in vivo abundance. Cranioplastic applications using BMSCs require a 6- to 8-week period of in vitro expansion, which introduces the possibility for malignant transformation and acquisition of foreign antigens. ${ }^{20}$ Higher cell numbers achievable through ASC harvests and increased proliferation rates in vitro minimize these concerns. Although the promise of iPSCs for healing cranial defects has been repeatedly demonstrated in mice, safety concerns including teratoma formation and insertional mutagenesis persist. ${ }^{46}$ These concerns must be addressed and minimized prior to the use of iPSCs in clinical trials.

\section{Conclusions}

Large skull defects have presented clinical challenges since the earliest records of medicine. Recent advances in cranioplasty through use of autologous and alloplastic materials have enabled the repair of increasingly complicated cranial defects. However, cranioplasty is no simpler today than it was centuries ago, with a great deal of care required regarding sterility, flap sculpting and fixation, drain usage, and clinical outcomes, regardless of reconstructive material used. Reported complication rates today range from $16 \%$ to $40 \%$, with a general reoperation rate of $25 \% .^{14,26,38,110}$ Additionally, the optimal materials and approaches remain largely unclear, and the demands on an ideal substitute for decranialized bone are many. Such a biocompatible material should possess a number of features, including ease of sterilization, low thermal conductivity, radiolucency, and biomechanical reliability, all in a cost-effective manner.

In the operating room, surgical preferences for implant materials have traditionally been dictated by several factors, including personal experiences, institutional preferences, and available resources. Given many conflicting reports on the appropriate materials to use in particular conditions and the relative degree of complications across modalities, the evidence base remains slim pending further well-powered cohort studies and randomized clinical trials. However, in addition to highlighting the evolution of materials and techniques involved in the progression of cranioplasty over thousands of years, this review aims to underscore that the choice of ideal material should be made on a case-by-case basis. Whereas the main considerations of material selection in adults are related to cosmesis and biocompatibility, in pediatric populations, continuing skull growth is a consideration to be made that will greatly impact operative success. Therefore, before deciding on a particular reconstructive option, surgeons should take great care to evaluate individual patients and associated factors that may dictate operative success (i.e., surgical site, clinical history) before proceeding. A multidisciplinary team of specialists allows for combined expertise to maximize the cosmetic and structural result for patients. A free flap may also be needed on occasion to fill a softtissue void, or for a staged approach to expand the scalp to provide skin coverage so the wound will heal with the new implant in place. If such a comprehensive approach is adopted, given the wide array of materials that exist in the modern operating room and the expansive literature particular to these materials across a number of indications, satisfactory outcomes for patient and physician alike can be achieved.

\section{Acknowledgment}

We thank Ms. Cindy H. Samos for editorial assistance with the manuscript.

\section{References}

1. Aciduman A, Belen D: The earliest document regarding the history of cranioplasty from the Ottoman era. Surg Neurol 68:349-353, 2007

2. Al-Tamimi YZ, Sinha P, Trivedi M, Robson C, Al-Musawi TA, Hossain N, et al: Comparison of acrylic and titanium cranioplasty. Br J Neurosurg 26:510-513, 2012

3. Andrushko VA, Verano JW: Prehistoric trepanation in the Cuzco region of Peru: a view into an ancient Andean practice. Am J Phys Anthropol 137:4-13, 2008

4. Artico M, Ferrante L, Pastore FS, Ramundo EO, Cantarelli $\mathrm{D}$, Scopelliti D, et al: Bone autografting of the calvaria and craniofacial skeleton: historical background, surgical results in a series of 15 patients, and review of the literature. Surg Neurol 60:71-79, 2003

5. Baldo S, Tacconi L: Effectiveness and safety of subcutaneous abdominal preservation of autologous bone flap after decompressive craniectomy: a prospective pilot study. World Neurosurg 73:552-556, 2010

6. Balossier A, Durand A, Achim VV, Noudel R, Hurel S, Emery E: [Reconstruction of the cranial vault using CAD/CAMfabricated glass bioceramic implants.] Neurochirurgie 57:21-27, 2011 (Fr)

7. Barth A: Über histologische Befunde nach Knochenimplantationen. Arch Klin Chir 46:409-417, 1893

8. Bauer M, Hussl H, Anderl H, Wilflinseder P: [Principles, methods and results of treatment of frontal bone defects.] Chirurg 45:514-518, 1974 (Ger)

9. Beck C: Ueber eine neue Methode der Deckung von Schädeldefecten. Arch Klin Chir 80:266-271, 1906

10. bin Abdullah I: Alâim-i Cerrâhin. Istanbul: Süleymaniye Library, Hekimoglu Ali Pasa, number: 568, 911 AH/1505: folios $1 \mathrm{~b}, 2 \mathrm{a}$

11. Blair GA, Gordon DS, Simpson DA: Cranioplasty in children. Childs Brain 6:82-91, 1980

12. Blom EJ, Klein-Nulend J, Yin L, van Waas MA, Burger EH: Transforming growth factor- $\beta 1$ incorporated in calcium phosphate cement stimulates osteotransductivity in rat calvarial bone defects. Clin Oral Implants Res 12:609-616, 2001

13. Blum KS, Schneider SJ, Rosenthal AD: Methyl methacrylate cranioplasty in children: long-term results. Pediatr Neurosurg 26:33-35, 1997

14. Bobinski L, Koskinen LO, Lindvall P: Complications following cranioplasty using autologous bone or polymethylmethacrylate-retrospective experience from a single center. Clin Neurol Neurosurg 115:1788-1791, 2013

15. Borstlap WA, Heidbuchel KL, Freihofer HP, KuijpersJagtman AM: Early secondary bone grafting of alveolar cleft defects. A comparison between chin and rib grafts. J Craniomaxillofac Surg 18:201-205, 1990

16. Bruens ML, Pieterman H, de Wijn JR, Vaandrager JM: Porous polymethylmethacrylate as bone substitute in the craniofacial area. J Craniofac Surg 14:63-68, 2003

17. Cabraja M, Klein M, Lehmann TN: Long-term results following titanium cranioplasty of large skull defects. Neurosurg Focus 26(6):E10, 2009

18. Chandler CL, Uttley D, Archer DJ, MacVicar D: Imaging after titanium cranioplasty. Br J Neurosurg 8:409-414, 1994

19. Chase SW, Herndon $\mathrm{CH}$ : The fate of autogenous and homog- 
enous bone grafts. J Bone Joint Surg Am 37-A:809-841, 1955

20. Chatterjea A, Meijer G, van Blitterswijk C, de Boer J: Clinical application of human mesenchymal stromal cells for bone tissue engineering. Stem Cells Int 2010:215625, 2010

21. Chien CY, Tsai WB: Poly(dopamine)-assisted immobilization of Arg-Gly-Asp peptides, hydroxyapatite, and bone morphogenic protein-2 on titanium to improve the osteogenesis of bone marrow stem cells. ACS Appl Mater Interfaces 5:6975-6983, 2013

22. Choi SH, Levy ML, McComb JG: A method of cranioplasty using coralline hydroxyapatite. Pediatr Neurosurg 29:324327, 1998

23. Clune JE, Mulliken JB, Glowacki J, Rogers GF, Arany PR, Kulungowski AM, et al: Inlay cranioplasty: an experimental comparison of particulate graft versus bone dust. Plast Reconstr Surg 126:1311-1319, 2010

24. Cohen AJ, Dickerman RD, Schneider SJ: New method of pediatric cranioplasty for skull defect utilizing polylactic acid absorbable plates and carbonated apatite bone cement. J Craniofac Surg 15:469-472, 2004

25. Costantino PD, Friedman CD, Jones K, Chow LC, Sisson GA: Experimental hydroxyapatite cement cranioplasty. Plast Reconstr Surg 90:174-191, 1992

26. De Bonis P, Frassanito P, Mangiola A, Nucci CG, Anile C, Pompucci A: Cranial repair: how complicated is filling a "hole"? J Neurotrauma 29:1071-1076, 2012

27. Dobrotworski W: Die rippen als material zur knochenautoplastik. Zentralbl Chir 32:1081-1083, 1911

28. Ducati A: From Incan time to today, the unresolved problem of cranioplasty. World Neurosurg 82:e439-e441, 2014

29. Ducic Y: Titanium mesh and hydroxyapatite cement cranioplasty: a report of 20 cases. J Oral Maxillofac Surg 60:272276, 2002

30. Dujovny M, Aviles A, Anger C: An innovative approach for cranioplasty using hydroxyapatite cement. Surg Neurol 48: 294-297, 1997

31. Edwards MS, Ousterhout DK: Autogeneic skull bone grafts to reconstruct large or complex skull defects in children and adolescents. Neurosurgery 20:273-280, 1987

32. Eftekhar B, Dadmehr M, Ghodsi M, ParsaPour A, Ketabchi E: Cranial trephination in ancient Iran. Case illustration. J Neurosurg 106 (1 Suppl):70, 2007

33. Eppley BL, Hollier L, Stal S: Hydroxyapatite cranioplasty: 2. Clinical experience with a new quick-setting material. J Craniofac Surg 14:209-214, 2003

34. Erdal YS, Erdal ÖD: A review of trepanations in Anatolia with new cases. Int J Osteoarchaeol 21:505-534, 2011

35. Eufinger $\mathrm{H}$, Wehmöller M: Individual prefabricated titanium implants in reconstructive craniofacial surgery: clinical and technical aspects of the first 22 cases. Plast Reconstr Surg 102:300-308, 1998

36. Galicich JH, Hovind KH: Stainless steel mesh-acrylic cranioplasty. Technical note. J Neurosurg 27:376-378, 1967

37. Gautschi OP, Schlett CL, Fournier JY, Cadosch D: Laboratory confirmed polymethyl-methacrylate (Palacos)-hypersensitivity after cranioplasty. Clin Neurol Neurosurg 112:915916, 2010

38. Gooch MR, Gin GE, Kenning TJ, German JW: Complications of cranioplasty following decompressive craniectomy: analysis of 62 cases. Neurosurg Focus 26(6):E9, 2009

39. Gordon DS, Blair GA: Titanium cranioplasty. BMJ 2:478481, 1974

40. Grant FC, Norcross NC: Repair of cranial defects by cranioplasty. Ann Surg 110:488-512, 1939

41. Grant GA, Jolley M, Ellenbogen RG, Roberts TS, Gruss JR, Loeser JD: Failure of autologous bone-assisted cranioplasty following decompressive craniectomy in children and adolescents. J Neurosurg 100 (2 Suppl Pediatrics):163-168, 2004

42. Greene AK, Mulliken JB, Proctor MR, Rogers GF: Pediatric cranioplasty using particulate calvarial bone graft. Plast Reconstr Surg 122:563-571, 2008

43. Gurdjian ES, Webster JE, Brown JC: Impression technique for reconstruction of large skull defects. Surgery 14:876881,1943

44. Guyuron B, Shafron M, Columbi B: Management of extensive and difficult cranial defects. J Neurosurg 69:210-212, 1988

45. Hancock DO: The fate of replaced bone flaps. J Neurosurg 20:983-984, 1963

46. Hawley RG: Does retroviral insertional mutagenesis play a role in the generation of induced pluripotent stem cells? Mol Ther 16:1354-1355, 2008 (Letter)

47. Henry HM, Guerrero C, Moody RA: Cerebrospinal fluid fistula from fractured acrylic cranioplasty plate. Case report. J Neurosurg 45:227-228, 1976

48. Hock JM, Centrella M, Canalis E: Insulin-like growth factor I has independent effects on bone matrix formation and cell replication. Endocrinology 122:254-260, 1988

49. Holmes RE, Hagler HK: Porous hydroxyapatite as a bone graft substitute in cranial reconstruction: a histometric study. Plast Reconstr Surg 81:662-671, 1988

50. Itoh Y: Clinicopathological study of cranioplasty using freeze-preserved autogenous skull. J Tokyo Med Coll 49:550-564, 1991

51. Iwama T, Yamada J, Imai S, Shinoda J, Funakoshi T, Sakai $\mathrm{N}$ : The use of frozen autogenous bone flaps in delayed cranioplasty revisited. Neurosurgery 52:591-596, 2003

52. Jaberi J, Gambrell K, Tiwana P, Madden C, Finn R: Longterm clinical outcome analysis of poly-methyl-methacrylate cranioplasty for large skull defects. J Oral Maxillofac Surg 71:e81-e88, 2013

53. Jackson IJ, Hoffmann GT: Depressed comminuted fracture of a plastic cranioplasty. J Neurosurg 13:116-117, 1956

54. Joffe JM, Nicoll SR, Richards R, Linney AD, Harris M: Validation of computer-assisted manufacture of titanium plates for cranioplasty. Int J Oral Maxillofac Surg 28:309-313, 1999

55. Josan VA, Sgouros S, Walsh AR, Dover MS, Nishikawa H, Hockley AD: Cranioplasty in children. Childs Nerv Syst 21:200-204, 2005

56. Kasper EM, Ridgway EB, Rabie A, Lee BT, Chen C, Lin SJ: Staged scalp soft tissue expansion before delayed allograft cranioplasty: a technical report. Neurosurgery 71 (1 Suppl Operative):15-21, 2012

57. Kent JN, Zide MF: Wound healing: bone and biomaterials. Otolaryngol Clin North Am 17:273-319, 1984

58. Kline RM Jr, Wolfe SA: Complications associated with the harvesting of cranial bone grafts. Plast Reconstr Surg 95:520, 1995

59. Koenig WJ, Donovan JM, Pensler JM: Cranial bone grafting in children. Plast Reconstr Surg 95:1-4, 1995

60. Körlof B, Nylén B, Rietz KA: Bone grafting of skull defects. A report on 55 cases. Plast Reconstr Surg 52:378-383, 1973

61. Kübler N, Michel C, Zöller J, Bill J, Mühling J, Reuther J: Repair of human skull defects using osteoinductive bone alloimplants. J Craniomaxillofac Surg 23:337-346, 1995

62. Larrañaga J, Rios A, Franciosi E, Mazzaro E, Figari M: Free flap reconstruction for complex scalp and forehead defects with associated full-thickness calvarial bone resections. Craniomaxillofac Trauma Reconstr 5:205-212, 2012

63. Laurie SW, Kaban LB, Mulliken JB, Murray JE: Donor-site morbidity after harvesting rib and iliac bone. Plast Reconstr Surg 73:933-938, 1984

64. Lemée JM, Petit D, Splingard M, Menei P: Autologous bone flap versus hydroxyapatite prosthesis in first intention in secondary cranioplasty after decompressive craniectomy: a French medico-economical study. Neurochirurgie 59:6063, 2013

65. Levi B, Hyun JS, Montoro DT, Lo DD, Chan CK, Hu S, et al: In vivo directed differentiation of pluripotent stem cells for 
skeletal regeneration. Proc Natl Acad Sci U S A 109:2037920384, 2012

66. Levi B, James AW, Nelson ER, Vistnes D, Wu B, Lee M, et al: Human adipose derived stromal cells heal critical size mouse calvarial defects. PLoS ONE 5:e11177, 2010

67. Lin H, Ding X, Yin L, Zhai H, Liu H, Kassaee A, et al: The effects of titanium mesh on passive-scattering proton dose. Phys Med Biol 59:N81-N89, 2014

68. Liu JK, Gottfried ON, Cole CD, Dougherty WR, Couldwell WT: Porous polyethylene implant for cranioplasty and skull base reconstruction. Neurosurg Focus 16(3):ECP1, 2004

69. Longacre JJ, Destefano GA: Further observations of the behavior of autogenous split-rib grafts in reconstruction of extensive defects of the cranium and face. Plast Reconstr Surg (1946) 20:281-296, 1957

70. Longacre JJ, Destefano GA: Reconstruction of extensive defects of the skull with split rib grafts. Plast Reconstr Surg (1946) 19:186-200, 1957

71. Lu L, Yaszemski MJ, Mikos AG: TGF- $\beta 1$ release from biodegradable polymer microparticles: its effects on marrow stromal osteoblast function. J Bone Joint Surg Am 83-A (Pt 2 Suppl 1):S82-S91, 2001

72. Mankani MH, Kuznetsov SA, Wolfe RM, Marshall GW, Robey PG: In vivo bone formation by human bone marrow stromal cells: reconstruction of the mouse calvarium and mandible. Stem Cells 24:2140-2149, 2006

73. Marchac D, Greensmith A: Long-term experience with methylmethacrylate cranioplasty in craniofacial surgery. J Plast Reconstr Aesthet Surg 61:744-753, 2008

74. Matic D, Phillips JH: A contraindication for the use of hydroxyapatite cement in the pediatric population. Plast Reconstr Surg 110:1-5, 2002

75. Mehrara BJ, Disa JJ, Pusic A: Scalp reconstruction. J Surg Oncol 94:504-508, 2006

76. Moreira-Gonzalez A, Jackson IT, Miyawaki T, Barakat K, DiNick V: Clinical outcome in cranioplasty: critical review in long-term follow-up. J Craniofac Surg 14:144-153, 2003

77. Morestin H: Les transplantations cartilagineuses dans la chirurgie réparatrice. Bull Mem Soc Chir Paris 41:19942046, 1915

78. Muller W: Zur frage der tempoaren schadelresektion an stelle der trepanation. Zentralbl Chir 4:65, 1890

79. Mulliken JB, Glowacki J, Kaban LB, Folkman J, Murray JE: Use of demineralized allogeneic bone implants for the correction of maxillocraniofacial deformities. Ann Surg 194:366-372, 1981

80. Munro IR, Guyuron B: Split-rib cranioplasty. Ann Plast Surg 7:341-346, 1981

81. Munroe AR: The operation of cartilage-cranioplasty. Can Med Assoc J 14:47-49, 1924

82. Mynors R: A History of the Practice of Trepanning the Skull and the After-Treatment: With Observations Upon a New Method of Cure, Illustrated by a Case. Birmingham, UK: Piercy \& Jones, 1785

83. Oklund SA, Prolo DJ, Gutierrez RV, King SE: Quantitative comparisons of healing in cranial fresh autografts, frozen autografts and processed autografts, and allografts in canine skull defects. Clin Orthop Relat Res (205):269-291, 1986

84. Ono I, Gunji H, Kaneko F, Numazawa S, Kodama N, Yoza S: Treatment of extensive cranial bone defects using computerdesigned hydroxyapatite ceramics and periosteal flaps. Plast Reconstr Surg 92:819-830, 1993

85. Ousterhout DK, Baker S, Zlotolow I: Methylmethacrylate onlay implants in the treatment of forehead deformities secondary to craniosynostosis. J Maxillofac Surg 8:228-233, 1980

86. Ozerdem OR, Sen O, Anlatici R, Erdoğan B, Aydin V: Osteogaleal flaps in pediatric cranioplasty. Ann Plast Surg 49:127-132, 2002
87. Pang D, Tse HH, Zwienenberg-Lee M, Smith M, Zovickian $\mathrm{J}$ : The combined use of hydroxyapatite and bioresorbable plates to repair cranial defects in children. J Neurosurg 102 (1 Suppl):36-43, 2005

88. Pankratiev BE: Dead bone grafts to repair skull defects. Ann Surg 97:321-326, 1933

89. Patone H, Barker J, Roberge D: Effects of neurosurgical titanium mesh on radiation dose. Med Dosim 31:298-301, 2006

90. Pereira EA, Aziz TZ: Cranioplasty: plus ça change, plus c'est la meme chose. World Neurosurg 82:e433-e434, 2014

91. Petty PG: Cranioplasty: a follow-up study. Med J Aust 2:806-808, 1974

92. Piedra MP, Thompson EM, Selden NR, Ragel BT, Guillaume DJ: Optimal timing of autologous cranioplasty after decompressive craniectomy in children. J Neurosurg Pediatr 10:268-272, 2012

93. Pochon JP, Klöti J: Cranioplasty for acquired skull defects in children-a comparison between autologous material and methylmethacrylate 1974-1990. Eur J Pediatr Surg 1:199-201, 1991

94. Prolo DJ: Cranial defects and cranioplasty, in Wilkins RH, Rengachary SS (eds): Neurosurgery. New York: McGrawHill, 1996, Vol 2, pp 2783-2795

95. Prolo DJ, Burres KP, McLaughlin WT, Christensen AH: Autogenous skull cranioplasty: fresh and preserved (frozen), with consideration of the cellular response. Neurosurgery 4:18-29, 1979

96. Rakowski JT, Chin K, Mittal S: Effects of titanium mesh implant on dosimetry during Gamma Knife radiosurgery. J Appl Clin Med Phys 13:3833, 2012

97. Rathbun TA, Mallin R: A probable trephination: not an enlarged parietal foramen! Bull N Y Acad Med 55:717723,1979

98. Rawlings CE III, Wilkins RH, Hanker JS, Georgiade NG, Harrelson JM: Evaluation in cats of a new material for cranioplasty: a composite of plaster of Paris and hydroxylapatite. J Neurosurg 69:269-275, 1988

99. Reddi AH: Morphogenesis and tissue engineering of bone and cartilage: inductive signals, stem cells, and biomimetic biomaterials. Tissue Eng 6:351-359, 2000

100. Rifkinson-Mann S: Cranial surgery in ancient Peru. Neurosurgery 23:411-416, 1988

101. Rish BL, Dillon JD, Meirowsky AM, Caveness WF, Mohr JP, Kistler JP, et al: Cranioplasty: a review of 1030 cases of penetrating head injury. Neurosurgery 4:381-385, 1979

102. Rogers GF, Greene AK, Mulliken JB, Proctor MR, Ridgway EB: Exchange cranioplasty using autologous calvarial particulate bone graft effectively repairs large cranial defects. Plast Reconstr Surg 127:1631-1642, 2011

103. Röpke W: Zur frage der deckung von schädeldefekten. Zentralbl Chir 35:1192-1194, 1912

104. Sanan A, Haines SJ: Repairing holes in the head: a history of cranioplasty. Neurosurgery 40:588-603, 1997

105. Sessions RB, Wolfe SK, Moiel RH, Cheek WR: Wire mesh foundation for methyl methacrylate cranioplasty. Laryngoscope 84:1020-1030, 1974

106. Shoja MM, Agutter PS, Loukas M, Shokouhi G, Khalili M, Farhoudi M, et al: Cranioplasty in medieval Persia and the potential spread of this knowledge to Europe. Childs Nerv Syst 28:1993-1996, 2012

107. Shonka DC Jr, Potash AE, Jameson MJ, Funk GF: Successful reconstruction of scalp and skull defects: lessons learned from a large series. Laryngoscope 121:2305-2312, 2011

108. Simpson D: Titanium in cranioplasty. J Neurosurg 22:292293, 1965

109. Singh KA, Burstein FD, Williams JK: Use of hydroxyapatite cement in pediatric craniofacial reconstructive surgery: 
strategies for avoiding complications. J Craniofac Surg 21:1130-1135, 2010

110. Sobani ZA, Shamim MS, Zafar SN, Qadeer M, Bilal N, Murtaza SG, et al: Cranioplasty after decompressive craniectomy: an institutional audit and analysis of factors related to complications. Surg Neurol Int 2:123, 2011

111. Spence WT: Form-fitting plastic cranioplasty. J Neurosurg 11:219-225, 1954

112. Staffa G, Barbanera A, Faiola A, Fricia M, Limoni P, Mottaran R, et al: Custom made bioceramic implants in complex and large cranial reconstruction: a two-year follow-up. J Craniomaxillofac Surg 40:e65-e70, 2012

113. Steinhäuser EW, Hardt N: Secondary reconstruction of cranial defects. J Maxillofac Surg 5:192-198, 1977

114. Taggard DA, Menezes AH: Successful use of rib grafts for cranioplasty in children. Pediatr Neurosurg 34:149-155, 2001

115. Tark WH, Yoon IS, Rah DK, Park BY, Kim YO: Osteoconductivity of porous polyethylene in human skull. J Craniofac Surg 23:78-80, 2012

116. Tessier P: Dysostoses cranio-faciales (syndromes de Crouzon et d'Apert). Ostéotomies totals de la face, in Sanvenero-Rosselli G, Boggio-Robutti (eds): Plastic and Reconstructive Surgery: Transactions of the Fourth International Congress, Rome, October 1967. Amsterdam: Excerpta Medica, 1969, pp 774-783

117. Thesleff T, Lehtimäki K, Niskakangas T, Mannerström B, Miettinen S, Suuronen R, et al: Cranioplasty with adiposederived stem cells and biomaterial: a novel method for cranial reconstruction. Neurosurgery 68:1535-1540, 2011

118. Timmons RL: Cranial defects and their repair, in Youmans JR (ed): Neurological Surgery:, ed 2. Philadelphia: WB Saunders, 1982, Vol 4, pp 2228-2250

119. Urist MR: Bone: formation by autoinduction. Science 150: 893-899, 1965

120. Valentini V, Cassoni A, Marianetti TM, Romano F, Terenzi V, Iannetti G: Reconstruction of craniofacial bony defects using autogenous bone grafts: a retrospective study on 233 patients. J Craniofac Surg 18:953-958, 2007

121. van Gool AV: Preformed polymethylmethacrylate cranioplasties: report of 45 cases. J Maxillofac Surg 13:2-8, 1985

122. Vanaclocha V, Bazan A, Saiz-Sapena N, Paloma V, Idoate M: Use of frozen cranial vault bone allografts in the repair of extensive cranial bone defects. Acta Neurochir (Wien) 139:653-660, 1997
123. Verheggen R, Merten HA: Correction of skull defects using hydroxyapatite cement (HAC) - evidence derived from animal experiments and clinical experience. Acta Neurochir (Wien) 143:919-926, 2001

124. Viterbo F, Palhares A, Modenese E: Cranioplasty: the autograft option. J Craniofac Surg 6:80-83, 1995

125. Wang F, Hoang D, Medvecky M, Amankulor N, Teng E, Narayan D: A novel cranioplasty technique incorporating cancellous femoral bone and recombinant bone morphogenic protein 2. J Craniofac Surg 23:1083-1086, 2012

126. Wang JC, Wei L, Xu J, Liu JF, Gui L: Clinical outcome of cranioplasty with high-density porous polyethylene. J Craniofac Surg 23:1404-1406, 2012

127. Wiggins A, Austerberry R, Morrison D, Ho KM, Honeybul S: Cranioplasty with custom-made titanium plates -14 years experience. Neurosurgery 72:248-256, 2013

128. Williams L, Fan KF, Bentley RP: Titanium cranioplasty in a paediatric population. Br J Oral Maxillofac Surg 50 Suppl 1:S8, 2012 (Abstract)

129. Wong RK, Gandolfi BM, St-Hilaire H, Wise MW, Moses M: Complications of hydroxyapatite bone cement in secondary pediatric craniofacial reconstruction. J Craniofac Surg 22:247-251, 2011

130. Woolf JI, Walker AE: Cranioplasty: collective review. Int Abstr Surg 81:1-23, 1945

131. Yamada H, Sakai N, Takada M, Ando T, Kagawa Y: Cranioplasty utilizing a preserved autogenous bone flap coated with acrylic resin. Acta Neurochir (Wien) 52:273280,1980

132. Zins JE, Whitaker LA: Membranous versus endochondral bone: implications for craniofacial reconstruction. Plast Reconstr Surg 72:778-785, 1983

\section{Author Contributions}

Conception and design: Choudhri. Acquisition of data: Feroze, Walmsley. Drafting the article: Feroze, Walmsley. Critically revising the article: all authors. Reviewed submitted version of manuscript: Edwards, Choudhri, Lorenz.

\section{Correspondence}

Michael S. B. Edwards, Department of Neurosurgery, Stanford University School of Medicine, 300 Pasteur Dr., R211, Stanford, CA 94305. email: edwards9@stanford.edu. 